\title{
Waka Oranga: Personal Reflections
}

\author{
Margaret Poutu Morice, Alayne Mikahere-Hall, \\ Wiremu Woodard, Cherry Pye, Anna Hinehou Fleming, \\ Verity Armstrong, Anna Poutu Fay, Zoe Poutu Fay
}

\section{Whakarāpopotonga}

He mea tino whakahirahira te whaiwāhitahitanga i te haerenga o Waka Oranga mō ngā huānga katoa me ō rātau whānau. Kai raro iho nei ngā hurihuringa whakaaro whaiaro o ngā hūanga whānui o te rōpū me ō rātau whānau e tūhura ana i te whaiaro me te take o tō rātau hononga ki tēnei rōpū whakaora hinengaro whakahirahira.

\begin{abstract}
Being part of the journey of Waka Oranga has been deeply meaningful for all members and their whanau. Below are personal reflections from a range of members of the rōpu and their whānau, in which the writers explore the experience and meaning of their connection to and with this remarkable psychotherapy rōpū.
\end{abstract}

\section{Introduction}

Being connected to Waka Oranga, the Maori psychotherapy rōpū, has been deeply meaningful for all who have been associated with it. The reflections below from some of the current members of this rōpū and their whānau reflect the depth of these connections, and the significance of these connections for the writers. The inspirational journey upon which this waka continues to travel is glimpsed in the words offered below; it is hoped these words will inspire us all in the rich and complex cultural journey which is psychotherapy in Aotearoa New Zealand.

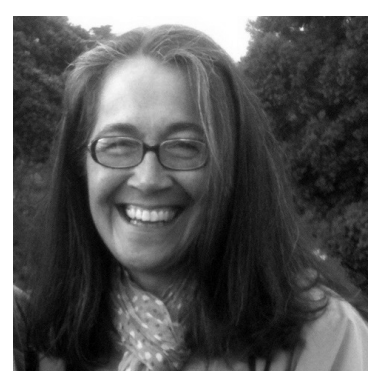

\section{Margaret Poutu Morice} Psychotherapy practitioner, Ongaonga

Waka Oranga is the National Roopu of Māori Psychotherapy Practitioners in Aotearoa New Zealand. Waka Oranga is the name gifted to us by our kaumatua Haare Williams, who has also been, since 1993, the Pae Arahi of the New Zealand Association of Psychotherapists (NZAP). It was Matua Haare's long-held vision that a Māori Caucus be established within

Morice, M. P., Mikahere-Hall, A., Woodard, W., Pye, C., Fleming, A. H., Armstrong, V., Poutu Fay, A., \& Poutu Fay, Z. (2019). Waka Oranga: Personal reflections. Ata: Journal of Psychotherapy Aotearoa New Zealand, 23(1), 35-48. https://doi.org/10.9791/ajpanz.2019.05 
NZAP, and this caucus is manifest in Waka Oranga.

Waka Oranga continues to play a small but significant part in the journey toward the recovery of Indigenous wisdom within the vast and complex field of social and mental health. It is my belief that well-being in contemporary Western societies are dependent, in part, upon the contributions of Indigenous wisdom. The interweaving of Indigenous traditions and Western perspectives has been a driving force in my work. Upholding traditional values of relationship continues to form a strong foundation for all our collective efforts.

The Māori (re)awakening that occurs through our own de-colonising experiences, complemented and supported by our Pākehā allies through their own consciousness-raising processes, has created a rich and fertile opportunity for cross-cultural engagements to emerge within the wider group of practicing psychotherapists in the Auckland region. Over a period of ten years, beginning in 2004, at regularly scheduled hui led by Nga Ao e Rua (The Two Worlds), Māori psychotherapy practitioners began to form and strengthen their collective voice.

In 2009 at the Christchurch/Ōtautahi NZAP Annual Conference, overwhelming support was expressed by NZAP members for Waka Oranga to be recognised as NZAP's Te Tiriti o Waitangi partner. Two seats at the NZAP Council table were reserved for Waka Oranga representatives. These were to be chosen by Waka Oranga members themselves rather than by the wider NZAP membership. Thus a partnership of genuine power sharing was established.

The recovery of Indigenous knowledge, and the provision of professional support for Māori psychotherapy training, practice, supervision and research continues to be the foundational kaupapa of Waka Oranga. This is not an easy task given the reality that support systems for Māori mental and social health have always been woefully inadequate. To carry responsibilities borne of whakapapa means facing enormous challenges and balancing complex and competing demands. We are a small group of Māori psychotherapy practitioners and although we derive loyal support from our Associate membership - a diverse group of mostly Pākehā and Tauiwi psychotherapy practitioners - we individually as Māori psychotherapy practitioners must also suffer the projections, envy and competitiveness of mainstream practitioners for whom our very existence is a threat.

I remain profoundly grateful to be able to work with a group of like-minded practitioners, all of whom are willing to embrace the scope and grapple with the tensions of bicultural relationships. As a founding member of both Nga Ao E Rua and Waka Oranga, I feel fortunate to discover myself, more fully myself amongst such brave companions.

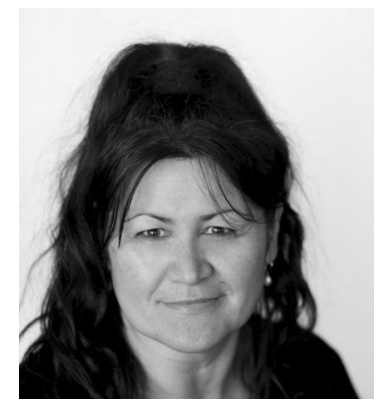

\section{Ehara toku toa i te toa takitahi, engari, he toa takimano e.}

My strength is not mine alone, but that of many.

\section{Alayne Mikahere-Hall Psychotherapy practitioner, Auckland}

The initiation and development of Waka Oranga begins with whakapapa originating from Atua and from Io mātua kore. 
This whakapapa goes a long way back before human life was shaped and formed. It is an extensive whakapapa and it is from this whakapapa that we as Māori have had our identities moulded and established. Whakapapa is the bedrock of our foundations, where whānau help to socialise who we become. Waka Oranga was birthed out of a desire to have who we are as Māori recognised and valued. It was born out of resistance and a refusal to take on board ideology that did not belong to us. It was also born out of an acceptance and understanding that psychotherapy and psychoanalysis had something to offer us. Like our primordial parents Papatūānuku (earth-mother) and Ranginui (sky-father), separated and yet both acting to nurture the children born of them.

What are the kinship ties that we have to each other in this waka of ours? It is the kaupapa, it is the purpose that binds us to each other, and it is whakapapa. What is the kaupapa, what is the purpose? The purpose is to make psychotherapy meaningful for Māori. To make things meaningful for Māori is to acknowledge and accept that the Māori world is real and valid. I held these beliefs long before I entered the mental health workforce, before I trained in psychotherapy and before I came to know my Māori friends, colleagues, peers and whānau in Waka Oranga. As a founding member of Waka Oranga I was motivated by the absence of an approach that would be more inclusive of Māori relational processes and techniques. That the modes of psychotherapy and the theories that fashion practice do not serve to privilege and advantage one group of people over another, or to alienate Māori.

Waka Oranga came into being in 2007, a significant time in NZAP's development where the "to be or not to be" questions were being raised concerning registration. It came at a time when there were competing interests and the distractions of registration and we were struggling to be recognised.

In 2006, representatives from the NZAP Treaty Committee, Council, and the Admissions Committee organised a meeting with interested Māori. The discussions focused on greater Màori participation and membership. A critique of the existing pathway to membership was talked through and deliberated on. It was at that meeting where I mooted the idea of a "Brown Book". I did this because I believed that a review of the existing "Orange Book" where slight amendments and a few suggested Māori terms would not serve Māori well enough. The suggestions would not go far enough to integrate our mātauranga Māori (Māori knowledge). Like many Indigenous cultures we have adapted and struggled to hold onto our tikanga, te reo and collective responsibilities to each other. The language of psychotherapy and the English language differs and there are inherent assumptions that operate within these languages. Furthermore, the suggested "Brown Book" would give Māori trained in psychotherapy the opportunity to critique the nature of our work from both a Māori and Western perspective. No one was aware at that time how long the journey would take to develop the "Brown Book". It has now morphed into He Ara Māori Advanced Clinical Practice (HAMACP). He Ara Mãori Advanced Clinical Practice is a Māori pathway; it recognises that Māori descend from a philosophical view of the world that comes with its own knowledge base. HAMACP also recognises that not all Mãori experiences are the same. HAMACP has had a number of iterations and we have needed to do this to capture various assessment processes. The process of full membership to NZAP is a committed and lengthy process that can take up to 5 years. The HAMACP committee members believe that we have undertaken a number of assessment processes that now enables us to finalise the pathway. In partnership, Waka Oranga and NZAP 
have increased full Māori membership into both organisations.

The kaupapa has been the vehicle that has driven my involvement with Waka Oranga, however the roadmap was never clear. These first ten years have been hugely important for Waka Oranga in terms of developing our own professional identity, our relationships with each other and with the New Zealand Association of Psychotherapists. We were a very small, very hard working and committed group of Māori psychotherapists who have gradually grown. From the outset we were reliant on whānau to help us achieve our aspirations and today we continue to leverage off their aroha for us. We are humbled by the support of our associate members; to have this tautoko is a demonstration of our regard for each other and for a belief that we can do psychotherapy in Aotearoa New Zealand together. Together we are responsible for ensuring that psychotherapy in Aotearoa New Zealand is in accordance with Te Tiriti o Waitangi.

I remain optimistic about our future and look forward to our expansion. Excited by the prospect that our professional peers and Indigenous brothers and sisters in Australia have reached out to Waka Oranga, asking, "how did you do it and how can we do it too?" The invitation for Waka Oranga to live-stream a presentation to the Psychotherapy and Counselling Federation of Australia (PACFA) in 2019 puts us on an international platform.

It was more than 10 years ago that Haare Williams forged a relationship with NZAP and held a vision that would bring Māori and Pākehā together. It remains as a Te Tiriti o Waitangibased relationship that will serve to carry us into the future.

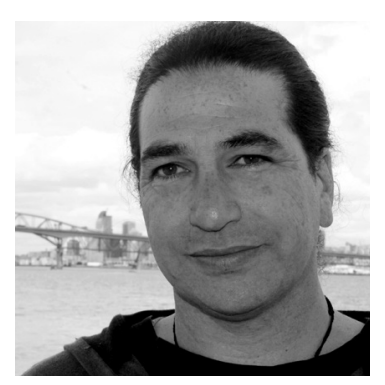

Wiremu Woodard Psychotherapy practitioner, Auckland

\section{Waka Oranga: He whakaaro noa mai i te pae. Some thoughts from the horizon}

Waka - a legacy of voyaging, intimately connected with the great diaspora of the peoples of Te Moana Nui a Kiwa. Waka vessels which are a part of our psyche, endowed with properties of movement, seeking, questing and returning. Waka - a container embodying dual principles of dynamism and stability. I was fortunate to be taught a karakia by our kaumātua Matua Haare Williams, Te Karakia a Tāne-mahuta. Tasked with reproducing the karakia word and metric perfect, I quickly fell into a rhythm of listening, reciting, listening, reciting, trying to capture nuances (not easy for me, a second language speaker) carried over millennia across the great oceans of Kiwa arriving on the shores of modern 21st century Aotearoa. Soon the rhythms lent themselves to a deeper meditation and research, immersing me in layers of meaning embedded in this ancient oral literature.

During a period of famine and war in ancient Hawaiki a version of this karakia was incanted by Maahu-Rangi, a tohunga, over the tree felled by Rakataura in the construction of the Tainui waka. (Similar versions are also recited for Te Arawa waka (Evans, 2009; Stafford, 1967/2016) and Ngātokimatawhaorua (Kaamira, 1957)). Part of the karakia states:

Piki ake ai au ki runga nei 
Ki te whare hukahuka no Tangaroa,

Tangaroa

I whatia a nukutaimaroro.

Cowan (1930) translated this, "I have mounted upon the great foaming girdle of the seagod Tangaroa, the waves beaten down and divided by the canoe Nuku-tai-maroro" (p.132). Similarly, Biggs (in Jones, 1995/2004) translated, "I will climb up here to the foam house of the sea god. The sea god embraced by ebb and tide beach" (p. 20). Best (1925) variated this translation, "Tangaroa who was broken on the sands of ebb and tide shore" (p. 67). Haare Williams (personal communication, 13 May 2018) interprets these lines as a feeling of endeavour, of daring, braving the vast ocean, a sense of human determination (and fear) foregrounded against the immensity and absolute power of elemental nature. Even within these two small lines there are multiple avenues of exploration and possibilities from which to draw meaning and understanding/wisdom. This karakia reminds us that the dispersal of peoples sailing, navigating Te Moana Nui a Kiwa was not a human-centric endeavour - we were borne here on waka hulled from forest giants (already intimately entwined with humanity, see Jones, 1995/2004, pp. 16-18), gifted and used only with permission, imbued with energy and vitality. Drawn from a universal energy field/grid, these waka are rākau tipua, elemental creatures, leviathans in their own right who held and carried our peoples across the vast trackless expanse of the great ocean of Kiwa (for an interesting comparison between Pacific wayfaring methods/technology and the mid-2oth century space missions to the moon listen to Wade Davis's (2009) Massey Lecture series, The Wayfinders).

Oranga - vitality, life itself. Waka Oranga - a vessel for the expression of unlimited creative energies. A seed?

In 1998 , almost ten years before forming and naming the fledgling collective of Maori psychotherapists/practitioners "Waka Oranga", Haare Williams, who had been approached to consult to the New Zealand Association of Psychotherapists (NZAP), challenged the Association to reflect on issues of monoculturalism and racism inherent in psychotherapy -

Whose culture is my organisation serving? Who makes the decisions and to whose benefit? To change your organisation, you will need to analyse and answer these questions. Most organisations in New Zealand are monocultural and therefore work to the advantage of the dominant group... (in Carson, Farrell \& Manning, 2008, pp.378-379)

Haare's wero reminds us that Waka Oranga is a not a single hulled waka but a double, he waka hourua. Understanding the roots of this dual construction allows a glimpse into our bicultural heart - conceived both as an aspirational counterpoint to contemporary Maori realties, a voice for whānau besieged, marginalised and suffering, as well as a lens to focus a critique of imperial (anti-democratic), nihilistic qualities inherent in the dogma of Western psychotherapy. However, this narrative is not a simple sentimental story of Māori victims and Pākehā victimisers. Waka Oranga is a double-hulled waka; a group of peoples drawn across Te Moana Nui a Kiwa and the Pacific on a great wave; historical epochs, salty tears, blood, sweat, triumphs, defeats and disasters - deposited on this beach, this shore of the 
present. We are a collection of jetsam and flotsam, tititai, floating on the great tide of history, Te Tai Nui; a multi-faceted collection of imperfect wood shavings gathered from the adzing of the great trees of the forest of Tāne; flawed and unique, and to quote Professor Cornell West, "shot through with multi-layered incongruities, contradictions, and [offering] imperfect forms of resistance against ugly structures of domination" (2004, p. 15). Together, Waka Oranga and NZAP are a part of deep historical democratic movements and, like Rakataura (and Rata) we are confronted with a looming social/ecological catastrophe which demands our attention, body, mind, and soul - as we transit from the Holocene into the Anthropocene, a new geological epoch, can we learn to mediate our needs while staying in relationship with our interconnected and extended humanity (beyond the ethnosphere)? Can we inspire a way of living from the soul that transports us beyond our immediate materialistic, narcissistic and nihilistically impacted realities?

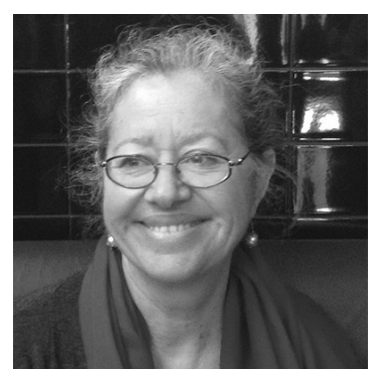

\section{Cherry Pye}

Psychotherapy practitioner, Ōtaki

\section{Waka Oranga and whanaungatanga}

The relatively short life of Waka Oranga has been one of flux. We have experienced births, deaths, marriages, graduations, departures, and arrivals. The only constant seems to have been change. It is from within this dynamic the roopu has evolved.

Like any new roopu, it required a dedicated core of people to stay committed to establishing and maintaining the kaupapa. The Waka has been fortunate to have that core. Exhausting as it has been at times, they are sustained and upheld by the tautoko received from their whānau, hapū, and iwi, from their associate membership of Pākehā and Tauiwi colleagues and friends. Also from their Tiriti relationship with NZAP. Whanaungatanga; the connections and relationships that drive our vision and that keep the waka afloat and moving forward, are central to the ongoing existence and success of the roopu.

Firstly, acknowledgement must be given to our kaumatua, Haare Williams. It is due to Matua Haare's wisdom and vision that Waka Oranga was born. In 1994, long before the roopu came into being Matua Haare, as Pae Arahi for the New Zealand Association of Psychotherapists (NZAP), was laying the foundations through his active engagement with the Association in developing biculturalism. His role as kaumatua offers a steady protective force. He provides mātauranga Māori which forms an essential base, the solidity and confidence necessary to move forward. He also offers inspiration as an accomplished poet and visual artist.

Hurihia to aroaro ki te ra tukuna to atarangi kia taka ki muri i a koe.

Turn your face to the sun and the shadows fall behind you.

Matua Haare is the sun to which we turn.

The importance of our kuia, Hinewirangi Kohu-Morgan cannot be overstated. She has 
also been with us from the beginning. With clear vision and strength, she keeps the waka pointed in the right direction, always reminding us of what is truly important. She is tohunga in many fields; including taonga puoro, poetry, hue carving and psychotherapy. Hinewirangi is our kaitiaki.

Ko te wāhine te kaitiaki o te wharetangata.

Women are the guardians of the past, present and future generations.

I recall with great fondness the inception of Waka Oranga, held at my partner Trevor's and my whare in the Kaimai, the ranges behind Katikati overlooking Tauranga Moana one weekend in 2007. As we gathered on the Friday evening, a call came from Hinewirangi informing us she was unable to attend the hui as her sister had passed away and she was on her way to the tangi in Tauranga. Bearing this in mind and holding Hinewirangi in our hearts we proceeded with the hui and spent several days connecting and envisioning the future of the roopu.

Particularly memorable was when Matua Haare spoke to and of the Kaimai and the old stories relating to these ranges. On the Saturday and Sunday mornings, looking outward from our deck we stood in the stillness and peace of dawn. Haare welcomed the day with karakia, followed by long ago stories of Tauranga Moana. Along with the presence of our delightful tamariki, the stories, myths, legends, karakia, kai, and sharings of who we were, culminated in Haare gifting us our name, Waka Oranga.

At the completion of the hui on Sunday, as is traditional, several of our roopu proceeded to Tauranga to Hinewirangi's marae to pay our respects at the tangi. Connecting with Hinewirangi and her whānau at this sad time gave a depth and significance to our beginnings which cannot be put into words.

An important feature of whanaungatanga is to include tamariki in all endeavours. Over the ten years of Waka Oranga's existence our tamariki have grown with us. Some are now about to enter university, some are pursuing academic careers, while others are following their respective dreams and aspirations. We now also have new members of the Waka, mokopuna, whose presence at our hui are an ever-present reminder of why we remain committed to the kaupapa of Waka Oranga. These precious little ones are our future.

The adhesive that keeps us connected is tikanga from Te Ao Māori; whanaungatanga and whakapapa. Forging and maintaining relationships with those from all iwi, and with our colleagues within NZAP is pivotal to the success of how the Waka proceeds.

He aha te mea nui? He tāngata, he tāngata, he tāngata.

What is the most important thing? It is people, it is people, it is people.

Ko Takitimu me Mataatua me Tainui ngā waka

Ko Mauao te maunga

Ko Tauranga Moana te moana

Ko Ngāti Ranginui me Ngāi Te Rangi ngā iwi

Ko Cherry Pye taku ingoa. 


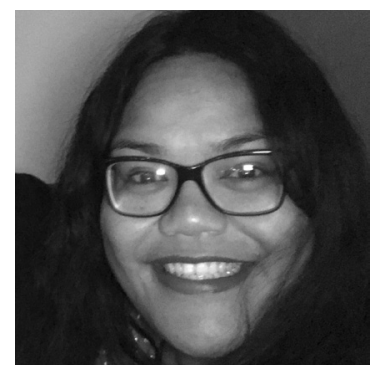

\section{Anna Hinehou Fleming Psychotherapist, Auckland}

\section{He aha te kai ō te rangatira? He kōrero, he kōrero, he kōrero. \\ What is the food of the leader? It is knowledge, it is communication.}

When I think of waka, many different images come to my mind. I think of the great ocean navigating vessels which our tuppuna sailed to Aotearoa. I think of the people who they transported, and the knowledge that they brought with them. I think of the trees that were carved into these mighty waka, and the connection that the waka builders had to the environment around them as they crafted.

For me, my mind travels just as broadly when I think of Waka Oranga. Our waka is small but has always had a number of extremely wise and dedicated people on board, committed to our kaupapa of upholding and uplifting Māori health. I think of Whaiora Marae which has sustained our waka from its earliest days and has held us through many celebrations, wananga and hui of many forms. I think of the different spaces where our members have shared their knowledge and various perspectives.

I first learned of Waka Oranga while I studied psychotherapy at Auckland University of Technology. Margaret Poutu Morice visited our Māori students’ rōpū, Ngā Pihinga Hinengaro, and while sharing about the kaupapa and latest news about Waka Oranga, invited us to attend their next hui. I did, and felt extremely out of my comfort zone as a student amongst many practicing psychotherapists and some of my lecturers. Being on a marae also brought with it a multitude of emotions as the hui continued. However, I experienced these alongside many warm faces, people who were interested in my stories and my perspectives and I was given many invitations to return.

I'm glad I accepted their invitations. Waka Oranga has been such a valuable part of my growth as a psychotherapist and as a wahine Māori. I have been able to take on different roles within the waka and have been supported and guided along the way. Following kaupapa Māori values and acknowledging the political, social and spiritual context of our lives is key to my practice as a psychotherapist, and finding a home which not only supports but champions this has felt extremely supportive and fulfilling. I have felt fortunate to be part of our mahi and to be participating in the ways that I can.

As I close this kōrero, I would like to mihi to our waka and to those who have and who continue to paddle. The journey that our waka is taking is impacting our people now and into the future.

Tōku toa, he toa rangatira.

My bravery is inherited from the chiefs who were my forebears. 


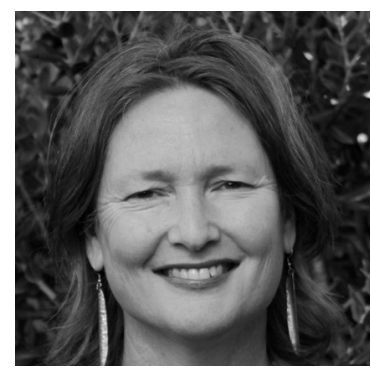

\section{Verity Armstrong Psychotherapist, Auckland}

I first learnt about Waka Oranga as a psychotherapy student at Auckland University of Technology. I was aware that there were staff members who had been involved in providing a supportive space or waka for Māori psychotherapy in Aotearoa. During my psychotherapy training I was able to fully experience myself as Māori. I was invited into this by staff and students who understood the impact of colonisation on my connection to whakapapa, and knew the healing power of reconnection with culture. Because of this cultural, emotional, physical and spiritual experience during my training, I decided to write my thesis about my view of the impact of colonisation on my whānau and how members of my whānau were experiencing the process of decolonisation.

This work, alongside my growing experience of psychotherapy in Aotearoa,led me towards Waka Oranga. I heard the cry of the Waka Oranga kuia, Hinewirangi, who asked us to decide, if you are going to be in the waka, then be in the waka! The sense of feeling "outside" the waka echoed my experience of being "outside" of my Māoriness. I joined the waka and continue to experience this discomfort, a helpful reminder of my tūpuna's experiences as the "other". What also grows alongside this is my understanding and felt sense of my Kai Tahu-ness.

Kai Tahu had their own experience of colonisation in Aotearoa, as did my whānau, with my tūpuna wāhine marrying European men who came to the bottom of Te Waipounamu looking for work and refuge. As I grow in my sense of strong identity with those Kai Tahu who left their home, and are working to reconnect, I also grow in my identity as a Māori psychotherapist working in Aotearoa.

I am deeply grateful to Waka Oranga for the opportunities to sit in these oftenuncomfortable spaces and to be held with aroha and manaaki at those times. I am also grateful for opportunities to learn and inhabit tikanga, not necessarily Kai Tahutanga but beautiful tikanga from the hearts, minds, bodies and souls of the tāngata of Waka Oranga.

As a newer waka member, I do not hold the history of the waka which my tuakana are such strong stewards of. My wish for the waka in the future is continued acknowledgement of the importance of the past. I also hold strong to the voices of the waka to make room for Māori psychotherapy in Aotearoa, as a way of healing for Māori in this land.

I also find joy in the thought of the continued and deep nourishment of the waka. As practitioners working in this field, we continue to strive for deeper self-care. As Māori living in Aotearoa, there are ways we can nourish ourselves deeply. I am loving being part of an adult kapa haka group at my children's kura this year. Our waka also plans a nourishing wananga over a weekend later in the year. This is our necessary mahi and soul kai.

Ko Takitimu te mauka

Ko Aparimu te awa

Ko Takitimu te waka

Ko Takutai o te Titi te marae

Ko Kai Tahu, Kati Mamoe te iwi

Ko Kuini Goodwillie toku tupuna

Ko Verity Armstrong taku ingoa. 


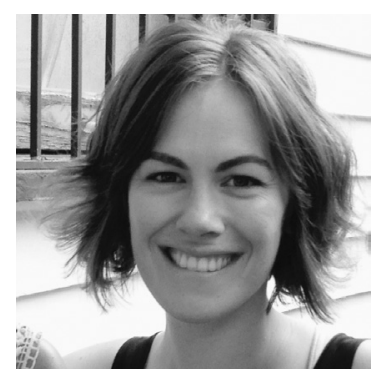

\section{Anna Poutu Fay}

When I started my $\mathrm{PhD}$ in 2013, I went to introduce myself to the fellow $\mathrm{PhD}$ student who had the neighbouring cubicle in our open office space and found myself drawn to a quote that was tacked up above her computer: "Kaupapa Māori theory and practice is not a neutral discourse, it is inextricably linked to the Māori struggle for self-determination”. I immediately recognised the quote and felt immense pride when I realised that it was from my mother's Master's thesis.

That experience of finding that Mum's words were recognised in a wider Māori research space affirmed much of what I already knew about Mum and her work, but it also confirmed more broadly, for me, what it means to have collective responsibility to address Māori needs and realise Māori aspirations. This consciousness is both a privilege and an obligation and requires active engagement in principles of relationship and responsibility.

As I came to find through my own research and study, being engaged in the struggle for selfdetermination inevitably leads to key tensions that appear to transcend discipline and profession. Institutional environments are often supportive in principle, yet resistant in practice to the aspirational goals of biculturalism. For example, where non-Māori feel included in Māori ceremony and celebration, attitudes are positive and evidence of indigeneity is often warmly embraced. Where non-Mãori feel excluded, however, as in the case of demands for sovereignty or power-sharing, attitudes tend to be more antagonistic, with little tolerance for power-sharing or political equity. It appears that often, indigeneity can only be embraced and celebrated if the politics of being Indigenous are absent. However, if the aspirations of partnership are to be realised, partnership must be based on actual and real equality. Formal and symbolic rituals and observances may signal shared aspirations to equality, but they do not bring it about. This raises the question of Indigenous advocacy - from those who knew the issues best by virtue of living them daily, versus non-Indigenous advocacy - from those who could stand in solidarity and remind their non-Indigenous colleagues of the moral obligation to support Indigenous peoples who continue to suffer the legacy of colonial oppression. Partnership activism involves contextually determining the most effective way to work collaboratively to effect change. With this comes considerable tension. Came (2012) framed her activist scholarship as a co-intentional approach which recognises that "the descendants of the colonisers have different decolonisation tasks from the descendants of the colonised" (Nairn, 2002, quoted in Came, 2012, p. 7). These differences demand recognition and respect.

I was 18 years old when Mum graduated with her Master's degree and 23 when Te Runanga o Waka Oranga was formed. The experience of being a daughter of a founding member of Te Runanga o Waka Oranga was fundamental in growing the collective conscious-ness in me, as well as illuminating just how much work, patience and tolerance is needed to be engaged in the struggle for Māori health equity. Equity requires not just reducing disparities but a new relationship in which the disparity is treated not as an anomaly but as a history. For Māori, as for other Indigenous peoples, the historical relationship is colonisation, which can only be overcome by a new relationship of partnership. Equity recognises the embeddedness of present-day power disparities and gives those disparities a history. As the foundational document of Aotearoa New Zealand, Te Tiriti o Waitangi underpins the claim to Māori 
sovereignty. To honour their Te Tiriti obligations, organisations and institutions in Aotearoa New Zealand are required to recognise Indigenous needs, rights and interests, consult with Indigenous collective authority regarding those needs, rights and interests, and in partnership with those authorities, evaluate the impacts of training and practice standards on the safety and wellbeing of Indigenous patients; the availability and quality of training opportunities for Indigenous health practitioners; the availability and quality of training opportunities for non-Indigenous practitioners who aspire to work with Indigenous patients in culturally appropriate ways; the development of bicultural and Indigenous ways of practicing; and the integration of Te Tiriti articles, principles and practices in health services across all specialties offered within Aotearoa New Zealand.

One of the main reasons that I was drawn to public health as a field was because I could find within it the understanding that it is at the community level that we really live our lives. The communities that my parents belong to and that my siblings and I were raised in and influenced by have affirmed and upheld our identities as Māori and as activists committed to the non-violent struggle for social justice. My hope is that my generation can continue to uphold and affirm what these communities instilled in us: the understanding that our rights as Māori are inalienable and cannot be ceded nor removed by those who do not honour them. It may be a struggle without end, but it is one with hope. Ngā mihi nui, ngā mihi aroha ki te roopu o Waka Oranga.

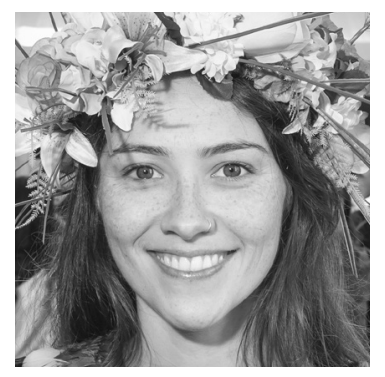

\section{Zoe Poutu Fay}

The begining of the rōpu that would eventually become Waka Oranga was started while I was an adolescent.

This was not only a journey for my mother but one that our entire whānau embarked on. My older sister Annie and I were brought on board (willingly!) in the role as tuakana for younger tamariki who were, like us, the children of mostly Māori colleagues of our mother who became the founding rōpū of Waka Oranga. I spent many weekends and school holidays with this whānau and community. My engagement with Waka Oranga was not only a formative experience but also a seamless one; it was a continuation of the Kaupapa Mãori education I have had since kohanga. I was fortunate enough to have been educated in a rumaki reo within a mainstream, lower decile, inner-city, predominantly Māori and Pasifika primary school, that was steeped in te reo me ona tikanga and held fast to the principles of equitable power-sharing between Tiriti partners. I understood from a young age what partnership between Māori and non-Māori actually looked like.

It was reflected atschool in the way my classroom wastaught,where whakawhanaungatanga and relationships were held above all else. It was reflected in the way my kura was run, where a commitment to Treaty principles was ever-present.

And it was, and continues to be, reflected at home in my parents' partnership as life partners, husband and wife, parents and colleagues. My siblings and I are, after all, the products of a crosscultural partnership between a mother who is tangata whenua, and a father who is tauiwi. 
The partnership between Waka Oranga and NZAP represented an embodiment of the equitable power-sharing relationships that I had already been immersed in. It was, for me, an expression of the cultural and political aspirations of Kaupapa Māori. As such, it was not without struggle - personal sacrifices for political recognition continue to be too high a price for individual Māori and their whanau, to suffer. But for as long as claims to rangatiratanga continue to be undermined, that struggle persists. In the face of these challenges, Waka Oranga has endured and remained steadfast. Its reclamation of Indigenous autonomy and wisdom has influenced my own mahi as an adult. My commitment to the kaupapa of decolonisation and justice has been deeply influenced by my experiences of participating at the heart of the creation, gestation and birth of Waka Oranga throughout my adolescence and young adulthood. This rōpū has helped positively foster my sense of obligation to my whānau, to my wider Māori community and to iwi taketake (Indigenous peoples) world-wide. In an increasingly individualistic and deficit-driven society, I believe this work is needed now more than ever, and I am so proud to be a seedling of this rōpū.

Nō reira, ki te rōpū manawarahi,

Nā koutou mā i tutuki te tai,

Nā koutou mā te ara i poka,

Kia kokiri whakamua!

\section{References}

Best, E. (1925). The Maori canoe. Dominion Museum Bulletin, 7. Wellington, New Zealand: Board of Māori Ethnological Research for the Dominion Museum.

Came, H. (2012). Institutional racism and the dynamics of privilege in public health (Doctoral thesis). University of Waikato, Hamilton, New Zealand.

Carson, R., Farrell, M., \& Manning, S. (2008). A history of a decade 1997-2006: Completing a chronology of the first sixty years 1947-2006. Wellington, New Zealand: The New Zealand Association of Psychotherapists, Te Roopu Whakaora Hinengaro.

Cowan, J. (1930). The Maori yesterday and today. Christchurch, New Zealand: Whitcomb \& Tombs.

Davis, W. (2009). The wayfinders: Why ancient wisdom matters in the modern world - Pt. 2. The 2009 CBC Massey Lectures. Retrieved from https://www.cbc.ca/player/play/1218115651762

Evans, J. (2009). Nga waka o nehera: The first voyaging canoes. Auckland, New Zealand: Oratia Media. Jones, P. (2004). Ngā iwi o Tainui: The traditional history of the Tainui people. Ngā kōrero tuku iho a ngā tupuna (B. Biggs, Trans.). Auckland, New Zealand: Auckland University Press. (Original work published 1995)

Kaamira, H. (1957). The story of Kupe (B. Biggs, Trans.). Journal of the Polynesian Society, 66(3), 232248. Retrieved from http://www.jps.auckland.ac.nz/document//Volume_66_1957/ Volume_66\%2C_No._3/The_story_of_Kupe $\% 2$ C_by_Himiona_Kaamira\%2C_p_232-248/p1

Stafford, M. D. (2016). Te Arawa: A history of the Te Arawa people. Auckland, New Zealand: Oratia Media. (Original work published 1967)

West, C. (2004). Democracy matters: Winning the fight against Imperialism. New York, NY: Penguin Books. 
Margaret Poutu Morice is a 64-year-old Māori woman of Ngāti Porou descent through her mother and Ngāti Maniapoto and Scottish ancestry through her father. She is the sixth of their eight children and their youngest daughter. Being both big sister and little sister, she flourished in her position in the family. Caring for others has been a central task of Margaret's life, so marrying into a family of psychotherapists and then becoming one herself has felt like a calling and a natural progression. She is committed to her work and the values to which she and other practitioners in Waka Oranga aspire to, and this continues to define who she is and what she does. Contact details: margaretmorice@xtra.co.nz.

Alayne Mikahere-Hall is kinship affiliated with Ngāti Whatua, Te Rarawa and Tainui. Alayne is a post-doctoral research fellow with Taupua Waiora Research Centre, Auckland University of Technology. She is the lead investigator on the Tūhono Māori research project, funded by the Health Research Council of New Zealand. Tūhono Māori is an investigation into a Mãori understanding of secure attachment. Alayne engages with Indigenous methodologies and Kaupapa Māori methods and theory. She has an interest in developing evidence-based Māori and Indigenous therapeutic interventions to develop theories concerning complex trauma. Alayne is also an investigator on the E Tū Wāhine, E Tū Whānau study, aimed at reducing the harmful effects of violence against women and families and to break cycles of complex whakapapa trauma (inter-generational family trauma). She is a current member of the Health Quality and Safety Commission Child Youth Mortality Review Committee and Nga Pou Arawhenua Mortality Review Committee. Alayne is a Registered Psychotherapist, a member of the New Zealand Association of Psychotherapists (NZAP) and a founding member of Waka Oranga - National Collective of Māori Psychotherapy Practitioners (NCMPP). Contact details: alhall@aut.ac.nz.

Wiremu Woodard is Tuhoe and an Indigenous therapist, father of four, activist, environmentalist, sometimes contemporary dancer and artist. Wiremu is committed to reducing health disparities for Māori and promoting social justice. He currently works in community practice at KERERU and teaches on the Psychotherapy and Counselling programme at Auckland University of Technology. Wiremu is a founding member of Waka Oranga - a group of dynamic Indigenous Māori practitioners committed to emancipatory freedom. Contact details: wiremu.woodard@aut.ac.nz.

Cherry Pye (Ngāti Ranginui, Ngāi Te Rangi) resides on the beautiful Kapiti Coast in the wonderful town of Ōtaki. She and her husband Trevor have been there for almost seven years and have seven children and 11 precious mokopuna. She commutes twice weekly to the CBD in Wellington and is in a practice with lovely colleagues and friends at City Psychotherapy. Cherry also has a home-based part-time psychotherapy/counselling practice in Ōtaki. Cherry is a founding and active member of Waka Oranga, the collective of Māori psychotherapy practitioners of Aotearoa. She is a full member of NZAC and NZAP with an Advanced Clinical Practice Certificate. Cherry trained at Auckland University of Technology in the early 1990 s in Integrative Gestalt Therapy. After 20 years of being in the psychotherapy and counselling field she has become much more interested and attuned to how wairua facilitates movement/ change in both the client and the therapist. Contact details: cherrympye@gmail.com. 
Anna Hinehou Fleming (Ngāpuhi, Ngāi Tūhoe) is a registered psychotherapist, serves on Te Rūnanga o Waka Oranga, National Collective of Māori Psychotherapy Practitioners and is a provisional member of the New Zealand Association of Psychotherapists. Anna has worked in various social and health services with individuals and whānau for over 14 years. In 2017, she graduated with a Master of Psychotherapy with first class honours. Her therapeutic approach combines her working and personal experiences with a focus on attachment and developmental theory particularly from a Māori perspective. This focus on Indigenous health informs Anna's current role as Counsellor for Māori at Auckland University of Technology, and her growing community practice in Tāmaki Makaurau. Contact details: fleming.anna@gmail.com.

Verity Armstrong is a Kai Tahu woman from Aotearoa New Zealand. She also has strong connections to clans MacKintosh and Armstrong. While her whakapapa is from the bottom of Te Waipounamu in the stunning Oraka/Aparima area, she grew up in Tāmaki Makaurau. Verity worked as a social worker in the area of childhood trauma, and then trained as a psychotherapist through AUT. She worked for an organisation specialising in domestic and sexual violence, and is now in private practice, specialising in sexual trauma. She also has an interest in sex positivism, relationships and love. Verity joined the runanga of Waka Oranga after experiencing their support and wisdom throughout her training and beginning years as a psychotherapist. Verity is married to her partner of many years, and has three tamariki. Her experience of mothering and being in relationship, and all of the learning this involves bring her a wealth of experiences, feelings and growth. Contact details: verityarmstrong@ gmail.com.

Anna Poutu Fay is a descendant of Te Hapu o Tuwhakairiora and Te Iwi o Ngāti Porou. She completed a joint PhD in Population Health at University of Auckland and University of Melbourne, graduating in 2018, and has worked as a public health researcher on a diverse range of projects. She is currently enjoying the privilege of being an at-home māmā to her 2-year-old daughter Ahi while she awaits the arrival of her second pēpi in September 2019. Contact details: annapfay@gmail.com.

Zoe Poutu Fay lives in Tàmaki Makaurau and works at the University of Auckland in the School of Māori Studies. She is working towards her PhD in Kaupapa Māori Education. She is the pōtiki of her whānanu (and behaves as such) but adores being an aunty more than anything. Contact details: zoelittlefay@gmail.com. 